\title{
Association between Atherosclerotic Diseases and Carboxyhaemoglobin Levels in Tobacco Smokers
}

\author{
NICHOLAS WALD, SUSANNAH HOWARD, P. G. SMITH, KNUD KJELDSEN
}

British Medical fournal, 1973, 1, 761-765

\begin{abstract}
Summary
In a cross-sectional study carboxyhaemoglobin (COHb) levels in tobacco smokers were found to provide a better indication of a person's risk of having developed certain atherosclerotic diseases, including ischaemic heart disease, than the smoking history. In the age group 30-69 years a person with a $\mathrm{COHb}$ level of $5 \%$ or more was found to be 21 times (lower $95 \%$ confidence limit 3.3 times) as likely to be affected by these diseases as another person of the same age and sex with similar smoking history and current smoking habits but with a COHb level of less than $3 \%$.
\end{abstract}

\section{Introduction}

There is a well recognized correlation between smoking and atherosclerosis. Prospective American studies have shown that men aged 40-49 who smoke 40 cigarettes a day have five times the risk of dying from ischaemic heart disease compared with non-smokers (Hammond, 1972). British data have shown that moderate cigarette smoking (more than 15 a day) trebles the risk of dying from ischaemic heart disease in men aged 45-54 (Doll and Hill, 1964).

A smoker's risk of developing atherosclerosis is likely to be more closely related to the amount of tobacco smoke absorbed than to the amount of tobacco smoked. Carboxyhaemoglobin $(\mathrm{COHb})$ can be used as a measure of tobacco smoke absorption since carbon monoxide (CO) is present in tobacco smoke in concentrations of about $4 \%$ (Wynder and Hoffman, 1967). It

D.H.S.S. Cancer Epidemiology and Clinical Trials Unit, Department of the Regius Professor of Medicine, University of Oxford, Radcliffe Infirmary, Oxford OX2 6HE

NICHOLAS WALD, M.R.C.P., Lecturer in Medicine

SUSANNAH HOWARD, M.SC., Research Officer

P. G. SMITH, B.SC., Research Officer

Department of Clinical Chemistry A, Rigshospitalet, Copenhagen KNUD KJELDSEN, M.D., Head of Department readily diffuses through the lungs and is avidly taken up by haemoglobin to form the stable pigment COHb.

The percentage COHb saturation is determined by a number of factors, including tobacco consumption, concentration of $\mathrm{CO}$ in tobacco smoke, depth of inhaling, $\mathrm{CO}$ pulmonary transfer factor, and atmospheric CO levels. Atmospheric CO very rarely results in COHb levels above $2.5 \%$ (Lawther and Commins, 1970). Values above this are usually the result of smoking and may reach $15 \%$ in heavy smokers (Goldsmith, 1970).

A $\mathrm{COHb}$ value provides information on tobacco smoke absorption, and therefore incorporates information on depth of inhaling as well as recent tobacco consumption. Ideally, a blood marker of daily tobacco smoke absorption should remain constant throughout the day for a given exposure to tobacco smoke. However, $\mathrm{COHb}$ has a half-life of only about four hours in resting men breathing air (Roughton and Root, 1945), so allowance must be made for this loss or the timing of the estimation standardized in relation to smoking.

Our aim is to show that COHb levels can be used to discriminate between persons having certain atherosclerotic diseases and persons without these diseases more accurately than is possible by using smoking history alone, and thus to suggest that this may be a good indicator of risk.

\section{Methods}

This paper is based on data collected by one of us (K.K.) as part of an epidemiological investigation of $\mathrm{COHb}$ and serum cholesterol in Danish smokers (Kjeldsen, 1969).

A total of 1,085 volunteers who worked for several firms in Copenhagen, including three tobacco companies, responded to an appeal for help in a study of arterial disease and smoking. Each subject completed a questionnaire about his smoking habits and any past medical history of vascular disease. All those giving a history suggestive of vascular disease were examined and the presence of myocardial infarction, angina pectoris, or intermittent claudication was confirmed from past medical records using the criteria shown in table I. Venous blood samples were taken from 1,083 people (two refused) at about the same time of the day (after lunch) and after the 
subjects had smoked as usual that day. Serum cholesterol and blood $\mathrm{CO}$ estimations were performed on each blood sample. Serum cholesterol was estimated by the method described by Richterich (1965) and the percentage COHb saturation was estimated as described by Hellung-Larsen et al. (1966).

Of the 1,083 people in the study 133 were excluded from the analysis (one affected and 132 unaffected persons) for the following reasons: elapse of more than one hour between smoking and venesection (one affected and 93 unaffected); unsatisfactory records (36 persons); and diseases influencing serum cholesterol levels (three persons with diabetes or thyroid disease). The distribution of ischaemic heart disease and intermittent claudication in the remaining 950 persons is shown in table $I$.

A person was considered to be a smoker if he currently smoked at least one cigar, one cigarette, or $1 \mathrm{~g}$ pipe tobacco a day; others, including ex-smokers, were regarded as nonsmokers. Of the 56 ex-smokers, one was affected. Subjects were divided into light, moderate, or heavy smoking categories

TABLE 1-Distribution of Atherosclerotic Diseases in the Study Population and Diagnostic Criteria for the Specified Diseases

\begin{tabular}{|c|c|c|c|c|c|}
\hline \multirow{2}{*}{\multicolumn{3}{|c|}{ Atherosclerotic Disease }} & \multicolumn{3}{|c|}{ Number Affected } \\
\hline & & & \multirow[b]{2}{*}{$\begin{array}{r}\text { Men } \\
2 \\
1 \\
1 \\
2 \\
6 \\
4 \\
16\end{array}$} & \multirow{2}{*}{$\begin{array}{c}\text { Women } \\
\\
1 \\
1 \\
0 \\
0 \\
6 \\
6 \\
12\end{array}$} & \multirow[b]{2}{*}{$\begin{array}{r}\text { Total } \\
\\
3 \\
2 \\
1 \\
2 \\
12 \\
10 \\
28\end{array}$} \\
\hline $\begin{array}{l}\text { Ischaemic Heart Disease: } \\
\text { M.I. } .+ \text { A.P. } \quad \cdots \\
\text { M.I. + } \\
\text { M.I. + I.C. } \\
\text { M.I. + A.P. + I.C. } \\
\text { A.P. } \\
\text { A.P. + I.C. } \quad \cdots \\
\text { Intermittent claudication only }\end{array}$ & $\begin{array}{l}\cdots \\
\cdots \\
\cdots \\
\cdots \\
\cdots\end{array}$ & $\begin{array}{l}\because \\
\because \\
\because \\
\because \\
\cdots\end{array}$ & & & \\
\hline \multicolumn{2}{|c|}{$\begin{array}{l}\text { Total with atherosclerotic disease } \\
\text { Total without atherosclerotic disease }\end{array}$} & $\because$ & $\begin{array}{r}32 \\
395\end{array}$ & $\begin{array}{r}26 \\
497\end{array}$ & $\begin{array}{r}58 \\
892\end{array}$ \\
\hline All subjects & .. & .. & 427 & 523 & 950 \\
\hline
\end{tabular}

Criteria for Diagnosis: myocardial infarction (M.I.)-typical history + E.C.G. changes of infarction + elevated serum transaminase; angina pectoris (A.P.)cypical history + E.C.G. changes of ischaemia; intermittent claudication (I.C.)typical history

of the 58 affected persons, 51 worked in tobacco manufacturing factories and 56 were smokers.

TABLE II-Definition of Smoking Categories

\begin{tabular}{|c|c|c|c|}
\hline & Cigarettes & Pipe Tobacco & Cigars \\
\hline Light smoker & $\begin{array}{l}\text { Less than } \\
10 \text { a day }\end{array}$ & $\begin{array}{l}\text { Less than } \\
50 \mathrm{~g} \text { a week }\end{array}$ & $\begin{array}{l}\text { Less than } \\
5 \text { a day }\end{array}$ \\
\hline Moderate smoker & $10-20$ a day & $50-100$ g a week & 5-10 a day \\
\hline Heavy smoker & $\begin{array}{l}\text { More than } \\
20 \text { a day }\end{array}$ & $\begin{array}{l}\text { More than } \\
100 \mathrm{~g} \text { a week }\end{array}$ & $\begin{array}{r}\text { More than } \\
10 \text { a day }\end{array}$ \\
\hline
\end{tabular}

for each type of tobacco smoked (cigarette, cigar, and pipe) according to the criteria shown in table II.

\section{Results}

The data were subjected to two methods of analysis. Firstly, all smokers were considered collectively and divided into heavy, moderate, and light smoking categories based on the estimated total weight of tobacco they each smoked. Secondly, data relating to persons who currently smoked only cigarettes and those who currently smoked only cigars were analysed separately. Only one affected and 20 unaffected persons smoked only pipes.

\section{ALL SMOKERS}

Each smoker was allocated an estimated number of cigarettes or cigars or grammes of pipe tobacco according to his smoking category, as shown in table III. For example, a moderate cigarette smoker, smoking 10-20 cigarettes daily, was scored as smoking 15 cigarettes each day. Following previous practice (Doll and Hill, 1954) one cigarette was taken to contain $1 \mathrm{~g}$ and one cigar $3 \mathrm{~g}$ tobacco. The estimated total quantity of tobacco in grammes for each of the previously defined smoking categories is shown in table III. Subjects were then classified according to the total estimated weight of tobacco smoked each day into the following groups, as used by Doll and Hill (1964): nil; 1-14 g (light); 15-24 g (moderate); over $25 \mathrm{~g}$ (heavy).

TABLE III-Smoking Categories in Terms of Estimated Quantity of Tobacco in grammes

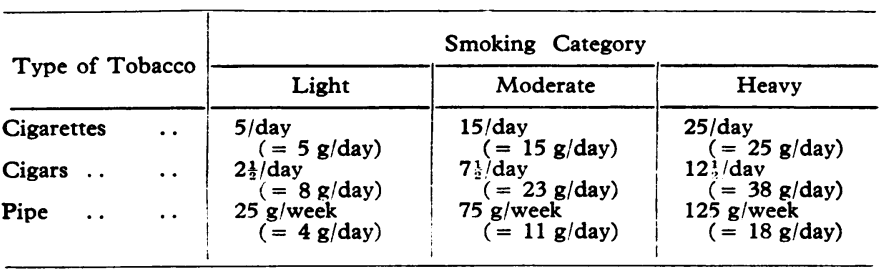

The proportion of affected persons classified by $\mathrm{COHb}$ level and total tobacco consumption is given in table IV. Light smokers rarely have high $\mathrm{COHb}$ levels, but heavy smokers frequently have low $\mathrm{COHb}$ levels. The proportion of affected persons increases with increasing $\mathrm{COHb}$ levels and, to a lesser extent, with increasing tobacco consumption. The relative

TABLE IV-Proportion of Subjects with Atherosclerotic Diseases grouped by COHb level and Combined Tobacco Consumption. Percentages in Parentheses

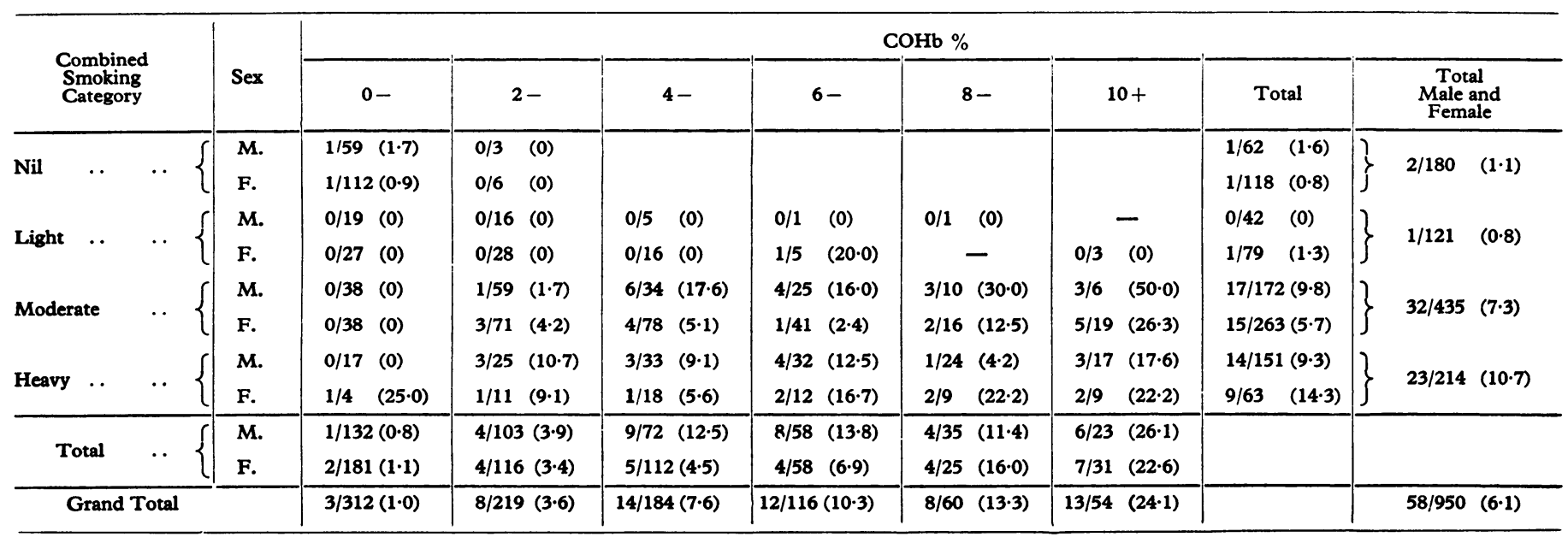


contribution of these two effects can be studied by observing the effect of increasing tobacco consumption in $\mathrm{COHb}$ groupings and the effect of increasing $\mathrm{COHb}$ in tobacco consumption categories.

For a given $\mathrm{COHb}$ level there is no clear increasing trend in the proportion of affected subjects with increasing tobacco consumption, but for a given smoking category there is a consistent effect of an increasing proportion of affected subjects as the $\mathrm{COHb}$ level rises.

Multiple regression analysis (using a logistic model with linear effects (Cox, 1970)) was used to investigate the relation between the proportion of affected persons and sex, age, years of past smoking, amount of cigarettes, amount of cigars, and amount of pipe tobacco smoked (each type of tobacco divided into the light, moderate, and heavy categories), serum cholesterol $(\mathrm{mg} / 100 \mathrm{ml})$, and $\mathrm{COHb}$ level in $0.5 \%$ gradations. The analysis which was restricted to the 625 smokers who were aged 30-69 years (since all the affected subjects were in this age range) showed that the only significant factors associated with the specified diseases were age, serum cholesterol, and $\mathrm{COHb}$.

The residual effect of all the remaining factors after allowing for age, $\mathrm{COHb}$, and serum cholesterol was not significant (table V).

TABLE v-Analysis of Variance: Significance of Age and $\mathrm{COHb}$ and Serum Cholesterol levels in All Persons

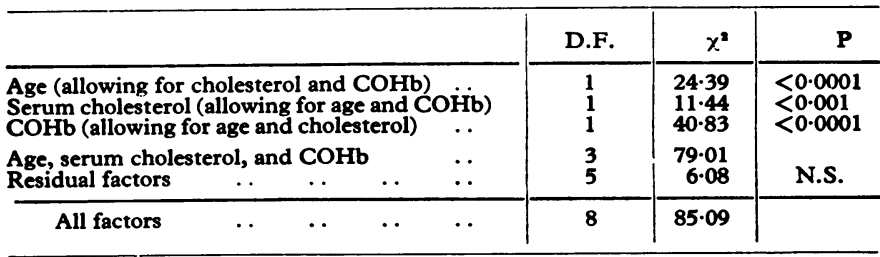

N.S. = Not significant. D.F. = Degrees of freedom.

The effects of cholesterol and COHb level were almost independent. There were no significant interactions between age, serum cholesterol, and $\mathrm{COHb}$ on the proportion of affected persons.

\section{PURE CIGARETTE SMOKERS}

The proportion of subjects with one or more of the specified atherosclerotic diseases according to their current cigarette consumption and their COHb level is given in table VI. Because of the small number of affected persons who smoked only cigarettes the sexes were combined and the $\mathrm{COHb}$ groups were broader than in the previous analysis. The ex- pected numbers of affected persons in each $\mathrm{COHb}$ group were calculated standardizing for all factors except $\mathrm{COHb}$ level. Results similar to those in table IV are shown.

Data on the 322 current pure cigarette smokers and the 126 non-smokers aged 30-69 years were investigated using multiple regression analysis and considering the same factors as before. It was found that the variation in the proportion of affected persons could be explained almost as satisfactorily by linear effects of $\mathrm{COHb}$ and age as by all six factors taken together. The small remaining effect of current cigarette consumption was not statistically significant (table VII).

TABLE VII-Analysis of Variance: Significance of Age, COHb level, and Cigarette Consumption in Pure Cigarette Smokers

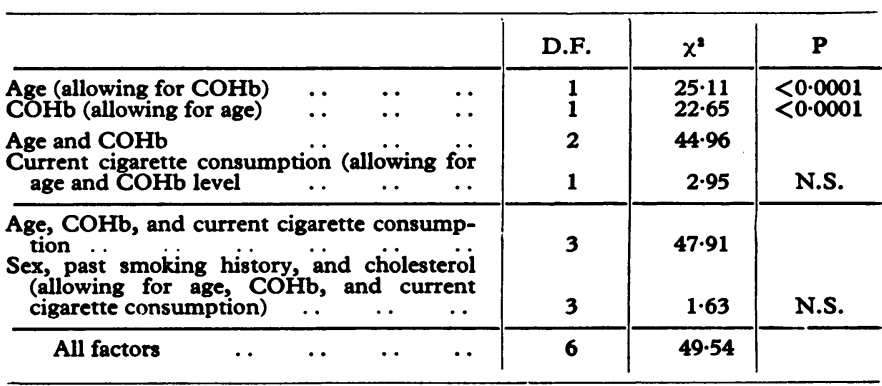

N.S. = Not significant. D.F. = Degrees of freedom.

The COHb effect and the effect of cigarette consumption on the proportion of affected persons was more noticeable among younger than among older persons. After allowing for age and tobacco consumption and their interaction, the effect of $\mathrm{COHb}$ was still statistically highly significant $(P<0.001)$.

\section{PURE CIGAR SMOKERS}

The proportion of affected subjects according to their current cigar consumption and $\mathrm{COHb}$ level is shown for pure cigar smokers and non-smokers in table VIII. Again there is an association between $\mathrm{COHb}$ level and the frequency of ischaemic disorders, though it is less pronounced than among cigarette smokers. The lack of such an effect among heavy smokers may be due to chance as there were only six affected persons.

Multiple regression analysis applied to data on the 166 pure cigar smokers and the 126 non-smokers aged 30-69 years indicated that the variation in the proportion of affected persons could be as satisfactorily explained by the linear effects of $\mathrm{COHb}$, serum cholesterol, and length of smoking history as by all six factors together (table IX).

TABLE vi-Proportion of Pure Cigarette Smokers with Atherosclerotic Disease grouped by COHb level and Cigarette Consumption

\begin{tabular}{|c|c|c|c|c|c|c|c|c|c|c|c|c|c|c|c|}
\hline & & & & \multicolumn{9}{|c|}{ COHb \% } & \multirow{2}{*}{\multicolumn{3}{|c|}{ Total }} \\
\hline & & & & \multicolumn{3}{|c|}{$0-$} & \multicolumn{3}{|c|}{ 4- } & \multicolumn{3}{|c|}{$8+$} & & & \\
\hline & & & & \multirow{2}{*}{$\begin{array}{l}\text { No. of } \\
\text { Persons }\end{array}$} & \multicolumn{2}{|c|}{$\begin{array}{l}\text { Persons } \\
\text { Affected }\end{array}$} & \multirow{2}{*}{$\begin{array}{c}\text { No. of } \\
\text { Persons }\end{array}$} & \multicolumn{2}{|c|}{$\begin{array}{l}\text { Persons } \\
\text { Affected }\end{array}$} & \multirow{2}{*}{$\begin{array}{l}\text { No. of } \\
\text { Persons }\end{array}$} & \multicolumn{2}{|c|}{$\begin{array}{l}\text { Persons } \\
\text { Affected }\end{array}$} & \multirow{2}{*}{$\begin{array}{c}\text { No. of } \\
\text { Persons }\end{array}$} & \multicolumn{2}{|c|}{$\begin{array}{l}\text { Persons } \\
\text { Affected }\end{array}$} \\
\hline & & & & & No. & $\%$ & & No. & $\%$ & & No. & $\%$ & & No. & $\%$ \\
\hline $\begin{array}{l}\text { Non-smokers ... } \\
\text { Cigarette Consumption: } \\
\text { Light (0-9/day) } \\
\text { Moderate (10-20/day) } \\
\text { Heavy (21 +/day) ... }\end{array}$ & $\begin{array}{l}\cdots \\
\cdots \\
\cdots\end{array}$ & $\begin{array}{l}\cdots \\
\cdots \\
\therefore\end{array}$ & $\begin{array}{l}\cdots \\
\cdots \\
\because \\
.\end{array}$ & $\begin{array}{r}180 \\
48 \\
122 \\
21\end{array}$ & $\begin{array}{l}2 \\
0 \\
2 \\
1\end{array}$ & $\begin{array}{l}1.1 \\
0.0 \\
1.6 \\
4.8\end{array}$ & $\begin{array}{r}- \\
20 \\
126 \\
55\end{array}$ & $\begin{array}{r}- \\
0 \\
5 \\
5\end{array}$ & $\begin{array}{l}- \\
0 \cdot 0 \\
4 \cdot 0 \\
9 \cdot 1\end{array}$ & $\begin{array}{r}- \\
1 \\
20 \\
10\end{array}$ & $\begin{array}{l}- \\
0 \\
4 \\
3\end{array}$ & $\begin{array}{r}- \\
0.0 \\
20 \cdot 0 \\
30 \cdot 0 \\
\end{array}$ & $\begin{array}{r}180 \\
69 \\
268 \\
86 \\
\end{array}$ & $\begin{array}{r}2 \\
0 \\
11 \\
9\end{array}$ & $\begin{array}{r}1.1 \\
0.0 \\
4.1 \\
10.5 \\
\end{array}$ \\
\hline $\begin{array}{l}\text { Total ... } \\
\text { Expected } \\
\text { Observed/Expe }\end{array}$ & iff & $\begin{array}{l}\mathrm{d} \text { p } \\
\cdots\end{array}$ & & 371 & $\begin{array}{l}5 \\
8 \cdot 18 \\
0.61\end{array}$ & 1.3 & 201 & $\begin{array}{l}10 \\
10.38 \\
0.96\end{array}$ & $5 \cdot 0$ & 31 & $\begin{array}{l}7 \\
3.43 \\
2.04\end{array}$ & $22 \cdot 6$ & 603 & $\begin{array}{l}22 \\
22 \cdot 0 \\
-\end{array}$ & $3 \cdot 6$ \\
\hline
\end{tabular}

Expected numbers are obtained after standardization for the effect of age, sex, duration of smoking history, serum cholesterol level, and cigarette consumption. $\chi^{2}(5$ D.F. $)=12 \cdot 84, \chi^{2}(1$ D.F. -trend) $=12 \cdot 30, P$ P $<0.001$. These significance test
for presentation. The tests were based on the method described by Armitage (1966). 
TABLE VIII-Proportion of Pure Cigar Smokers with Atherosclerotic Disease grouped by COHb level and Cigar Consumption

\begin{tabular}{|c|c|c|c|c|c|c|c|c|c|c|c|c|c|c|c|}
\hline & & & & \multicolumn{9}{|c|}{ СOHb \% } & \multirow{2}{*}{\multicolumn{3}{|c|}{ Total }} \\
\hline & & & & \multicolumn{3}{|c|}{$0-$} & \multicolumn{3}{|c|}{$4-$} & \multicolumn{3}{|c|}{$8+$} & & & \\
\hline & & & & \multirow{2}{*}{$\begin{array}{l}\text { No. of } \\
\text { Persons }\end{array}$} & \multicolumn{2}{|c|}{$\begin{array}{l}\text { Persons } \\
\text { Affected }\end{array}$} & \multirow{2}{*}{$\begin{array}{c}\text { No. of } \\
\text { Persons }\end{array}$} & \multicolumn{2}{|c|}{$\begin{array}{l}\text { Persons } \\
\text { Affected }\end{array}$} & \multirow{2}{*}{$\begin{array}{l}\text { No. of } \\
\text { Persons }\end{array}$} & \multicolumn{2}{|c|}{$\begin{array}{l}\text { Persons } \\
\text { Affected }\end{array}$} & \multirow{2}{*}{$\begin{array}{l}\text { No. of } \\
\text { Persons }\end{array}$} & \multicolumn{2}{|c|}{$\begin{array}{l}\text { Persons } \\
\text { Affected }\end{array}$} \\
\hline & & & & & No. & $\%$ & & No. & $\%$ & & No. & $\%$ & & No. & $\%$ \\
\hline $\begin{array}{l}\text { Non-smokers ... .. } \\
\text { Cigar Consumption: } \\
\text { Light (1-4/day) } \\
\text { Moderate (5-10/day) } \\
\text { Heavy (11 +/day) .. }\end{array}$ & $\begin{array}{l}. . \\
\cdots \\
\cdots\end{array}$ & $\begin{array}{l}. \cdots \\
\cdots \\
\cdots\end{array}$ & $\begin{array}{l}\cdots \\
\cdots \\
\cdots\end{array}$ & $\begin{array}{r}180 \\
19 \\
52 \\
8\end{array}$ & $\begin{array}{l}2 \\
0 \\
2 \\
3\end{array}$ & $\begin{array}{r}1.1 \\
0.0 \\
37.8 \\
37.5 \\
\end{array}$ & $\begin{array}{r}- \\
3 \\
38 \\
7\end{array}$ & $\begin{array}{l}- \\
1 \\
8 \\
1\end{array}$ & $\begin{array}{l}- \\
33 \cdot 3 \\
21 \cdot 1 \\
14 \cdot 3\end{array}$ & $\begin{array}{r}- \\
1 \\
28 \\
22\end{array}$ & $\begin{array}{l}- \\
0 \\
8 \\
2\end{array}$ & $\begin{array}{r}- \\
0 \cdot 0 \\
28 \cdot 6 \\
9 \cdot 1\end{array}$ & $\begin{array}{r}180 \\
23 \\
118 \\
37\end{array}$ & $\begin{array}{r}2 \\
1 \\
18 \\
6\end{array}$ & $\begin{array}{r}1 \cdot 1 \\
4 \cdot 3 \\
15 \cdot 3 \\
16 \cdot 2\end{array}$ \\
\hline \multicolumn{4}{|c|}{$\begin{array}{l}\text { Total .. } \\
\text { Expected* No. of affected persons } \\
\text { Observed/Expected }\end{array}$} & 259 & $\begin{array}{r}7 \\
10 \cdot 68 \\
0.66\end{array}$ & $2 \cdot 7$ & 48 & $\begin{array}{l}10 \\
8 \cdot 12 \\
1 \cdot 23\end{array}$ & $20 \cdot 8$ & 51 & $\begin{array}{l}10 \\
8 \cdot 20 \\
1 \cdot 22\end{array}$ & $19 \cdot 6$ & 358 & $\begin{array}{l}27 \\
27 \cdot 00 \\
-\end{array}$ & 7.5 \\
\hline
\end{tabular}
*Expected numbers are obtained after standardization for the effects of age, sex, duration of smoking history, serum cholesterol level, and cigar consumption.
$\chi^{2}(5$ D.F. $)=7 \cdot 36, x^{2}(1$ D.F. - trend $)=5.62, P<0.05$ (see note in table VI).

TABLE IX-Analysis of Variance: Significance of Cigar Smoking History and $\mathrm{COHb}$ and Serum Cholesterol levels in Pure Cigar Smokers

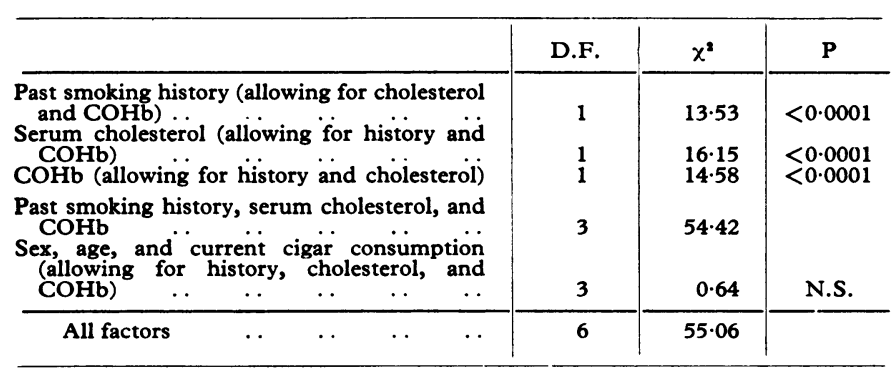

N.S. $=$ Not significant. D.F. $=$ Degrees freedom.

The $\mathrm{COHb}$ effect was more pronounced in persons with a short smoking history. After allowing for the effects of smoking history and serum cholesterol and their interaction, the effect of $\mathrm{COHb}$ was still statistically highly significant $(P<0.0005)$.

\section{RELATIVE RISK}

High COHb levels were found to be strongly associated with an increased frequency of atherosclerotic disease. All the 625 subjects used in the regression analysis on smokers of all types of tobacco were divided into groups matched by sex, age (in decades), years of smoking (in decades), and consumption of cigarette, cigar, and pipe tobacco. Type of tobacco was matched exactly. Forty-three of the groups, with 208 people in all, contained at least one affected person. From these matched groups the maximum likelihood estimate of relative risk was obtained in a manner similar to that given by Miettinen (1970). The relative risk for persons with $\mathrm{COHb}$ levels of $-5 \%$ or more compared with persons with less than $3.0 \% \mathrm{COHb}$ was $21 \cdot 2$ (95\% confidence limits $3 \cdot 3,734 \cdot 3$ ). The magnitude of risk did not vary significantly for different types of tobacco or for age or sex. The risk was similar in magnitude with respect to ischaemic heart disease and intermittent claudication.

\section{Discussion}

$\mathrm{COHb}$ was highly significantly associated with ischaemic heart disease and intermittent claudication even after allowing for serum cholesterol, age, and smoking history, which are known to be related to these diseases (Kannel et al., 1964, 1967).

The independent association of $\mathrm{COHb}$ level and atherosclerotic disease has not previously been reported and its strength suggests that raised $\mathrm{COHb}$ levels may be an important risk factor in atherosclerosis, including ischaemic heart disease. This does not mean, necessarily, that $\mathrm{CO}$ itself is atherogenic, although there is experimental evidence in animals, including primates, that this is the case (Webster et al., 1970; Kjeldsen et al., 1972). CO is nonetheless a useful marker of tobacco smoke absorption, and our data suggest that it is at least an indirect measure of the risk of ischaemic disorders.

In this study the time of venesection for $\mathrm{COHb}$ estimation was only approximately standardized in relation to the time of smoking. Nevertheless, of all the factors considered, $\mathrm{COHb}$ was still the most powerful discriminator between affected and unaffected persons.

There is no way, a priori, of knowing how to equate precisely the weight of tobacco smoked in cigarettes with that smoked in cigars or pipes in terms of the risk of ischaemic disorders. Unless data from mixed smokers are to be overlooked, some assumption regarding the relative equivalence of different types of tobacco seems to be justified. Alternative reasonable assumptions about the relative equivalence of the three types of tobacco were made and did not materially alter the results.

It could be argued that the sample population from which these data were collected was not representative because it consisted of volunteers and a high proportion of tobacco factory. workers. Neither of these facts, however, is likely to affect the observed association between high $\mathrm{COHb}$ levels and atherosclerotic disease. The high proportion of cigar smokers, $34 \%$ of whom were women, is clearly more typical of Denmark than Britain.

The results of the three analyses are consistent in showing a strong independent association between $\mathrm{COHb}$ and the specified atherosclerotic diseases but give divergent results regarding the effects of cholesterol and smoking history when cigarette and cigar smokers are examined separately. These divergent results probably reflect the peculiar sample population and the variability in the data, and we think that they should be interpreted cautiously. A greater effect of current tobacco consumption on the frequency of atherosclerotic diseases might have been detected (after allowing for the effect of $\mathrm{COHb}$ ) had it been possible to use smaller and more refined categories.

Data from a cross-sectional study in which affected subjects were aware of their disease cannot be used to predict atherosclerotic disease. It is possible that as a result of these diseases subjects altered their smoking habits so as to lead to higher $\mathrm{COHb}$ levels for a given cigarette consumption. This might occur if cigarettes were inhaled more deeply to compensate for a reduction prompted by medical advice. Though there is no way of determining whether such selective factors have produced a spurious association, the results suggest a strong association between high $\mathrm{COHb}$ levels and certain atherosclerotic diseases. We believe that this warrants further investigation by a prospective study, and this is now being undertaken in Oxford and London. 
We thank Sir Richard Doll, Dr. M. C. Pike, Dr. M. P. Vessey, Dr. L. J. Kinlen, and Mr. R. Peto for their helpful advice. We thank the director, Dr. J. Howlett, and the staff of the Science Research Council's Atlas Computing Laboratory for the provision of computer facilities. We also thank Gale Mead, Catherine Harwood, and Vivienne Williams for typing the manuscript.

\section{References}

Armitage, P. (1966). Fournal of the Royal Statistical Society 'B', 28, 150 Cox, D. R. (1970). Analysis of Binary Data. London, Methuen.

Doll, R., and Hill, A. B. (1954). British Medical fournal, 1, 1451.

Doll, R, and Hill, A. B. (1964). British Medical fournal, 1, 1399, 1460

Goldsmith, J. R. (1970). Annals of the New York Academy of Sciences, 174,122 .

Hammond, E. C. (1972). In Proceedings of the Second World Conference on Smoking and Health, London, 1971, ed. R. G. Richardson, London,
Hellung-Larsen, P., Kjeldsen, K., Mellemgaard, K., and Astrup, P. (1966) Scandinavian fournal of Laboratory Investigation, 18, 4443.

Kannel, W. B., Dawber, T. R., Friedman, G. D., Glennon, W. E., and McNamara, P. M. (1964). Annals of Internal Medicine, 61, 888.

Kannel, W. B., Castelli, W. P., and McNamara, P. M. (1967). Fournal of Occupational Medicine, 9,611 .

Kjeldsen, K. (1969). Smoking and Atherosclerosis. Copenhagen, Munksgaard.

Kjeldsen, K., Astrup, P., and Wanstrup, J. (1972). Atherosclerosis, 16, 67.

Lawther, P. J., and Commins, B. T. (1970). Annals of the New York Academy of Sciences, 174, 135.

Miettinen, O. S. (1970). Biometrics, 26, 75

Richterich, R. (1965). Klinische Chemie. Theorie und Praxis, p. 231. Basel, Korge.

Roughton, F. J. W., and Root, W. S. (1945). American fournal of Physiology, 145,239 .

Webster, W. S., Clarkson, T. B., and Lofland, H. B. (1970). Experimental and Molecular Pathology, 13, 36.

Wynder, E. L., and Hoffman, D. (1967). Tobacco and Tobacco Smoke. Studies in Experimental Carcinogenesis, p. 730. New York, Academic Press.

\title{
Double-blind Trial of Linoleate Supplementation of the Diet in Multiple Sclerosis
}

\author{
J. H. D. MILLAR, K. J. ZILKHA \\ M. J. S. LANGMAN, \\ H. PAYLING WRIGHT, A. D. SMITH, \\ J. BELIN, R. H. S. THOMPSON
}

British Medical fournal, 1973, 1, 765-768

percentage of linoleate in the phospholipids of platelets and erythrocytes is also significantly reduced in patients with multiple sclerosis (Gul et al., 1970). The possible significance

\section{Summary}

Seventy-five patients in London and Belfast with multiple sclerosis were given daily supplements of a vegetable oil mixture containing either linoleate or oleate for two years in a double-blind control trial. Relapses tended to be less frequent and were significantly less severe and of shorter duration in the linoleate-supplemented group than in those receiving the oleate mixture, but clear evidence that treatment affected the overall rate of clinical deterioration was not obtained.

\section{Introduction}

There have been several reports of changes in the relative proportions of saturated and unsaturated fatty acids in the brain lipids in multiple sclerosis (Gerstl et al., 1961; Baker et al., 1963; Cumings et al., 1965; Arnetoli et al., 1969; Clausen and Hansen, 1970; Gerstl et al., 1970; Alling et al., 1971) and also that the serum linoleate level is reduced in this desease (Baker et al., 1964; Tichy et al., 1969; Mahler, 1971). The

Department of Neurology, Royal Victoria Hospital, Belfast BT12 6BA J. H. D. MILLAR, M.D., F.R.C.P., Consultant Neurologist

National Hospital, Queen Square, London WC1

K. J. ZILKHA, M.D., F.R.C.P., Consultant Physician

Department of Medicine, General Hospital, Nottingham NG1 6HA M. J. S. LANGMAN, M.D., M.R.C.P., Consultant Physician and Professor of Therapeutics

Department of Pharmacology, Royal College of Surgeons, London WC1

H. PAYLING WRIGHT, PH.D., L.M.S.S.A., Member of External Staff, M.R.C. Thrombosis Research Ünit

Courtauld Institute of Biochemistry, Middlesex Hospital Medical School, London W1P 5PR

A. D. SMITH, B.SC., PH.D., Senior Lecturer in Biochemistry

A. BELIN, M.SC., Research Associate

J. H. S. THOMPSON, F.R.C.P., F.R.C.PATH., Professor of Biochemistry and Director of the Courtauld Institute of these biochemical abnormalities in relation to the pathogenesis of the disease has recently been discussed by Thompson (1973).

The view has also been put forward that the geographical incidence of multiple sclerosis and its higher prevalence in some parts of the world may be related to the amount of fat in the diet (Swank, 1950), and in particular to a deficiency of polyunsaturated fatty acids (Sinclair, 1956; Allison, 1963).

Supplementation of diets with linoleate is known to lead in healthy persons to an increase of linoleate in the serum lipid fractions together with a decrease of oleate and sometimes of palmitate, palmitoleate, and stearate. It has recently been shown that patients with multiple sclerosis are able to absorb linoleate from sunflower seed oil supplements as efficiently as healthy control subjects, as is shown by the similar increases in the serum linoleate levels produced in the two groups of subjects (Belin et al., 1971).

Since 1962 one of us (K.J.Z.) has given sunflower seed oil by mouth to 90 patients with multiple sclerosis, and the impression was gained that the clinical course of the disease was improved. Since these observations were uncontrolled, and since multiple sclerosis is a disease in which the clinical course is unpredictable, it was decided to conduct a double-blind trial jointly in London and Belfast in order to determine whether the oral administration of linoleate, taken in the form of daily doses of a sunflower seed oil emulsion, influenced the course of the disease.

After the trial had begun Swank (1970) gave an account of his experience in treating patients with multiple sclerosis over a 20-year period with a regimen involving a reduction of the saturated animal fats and a supplementation of the diet with unsaturated vegetable oils. Although his observations were also uncontrolled he concluded that "patients who consumed the least amount of fat and the largest amounts of fluid oils deteriorated less than those who consumed more fat and less oil."

A further change in the blood of multiple sclerosis patients is shown by the increased adhesiveness to glass of the platelets (Caspary et al., 1965; Payling Wright et al., 1965; Millar et al., 1966; Millac, 1967). This led us to study the platelet adhesive- 